TITLE:

\title{
Multiplayer Games as Extension of Misère Games(Abstract_要旨 )
}

$\operatorname{AUTHOR}(S)$ :

Suetsugu, Koki

CITATION:

Suetsugu, Koki. Multiplayer Games as Extension of Misère Games. 京都 大学, 2019, 博士(人間・環境学)

ISSUE DATE:

2019-03-25

URL:

https://doi.org/10.14989/doctor.k21863

RIGHT:

学位規則第9条第2項により要約公開 
（続紙 1）

\begin{tabular}{|l|l|l|l|}
\hline 京都大学 & 博士（人間・環境学 ） & 氏名 & 末續 鴻輝 \\
\hline 論文題目 & $\begin{array}{l}\text { Multiplayer Games as Extension of Misère Games } \\
\text { (逆形ゲームの拡張としての多人数ゲーム) }\end{array}$ \\
\hline
\end{tabular}

(論文内容の要旨)

組合せゲーム理論は、偶然性やプレイヤーに隠された情報の存在しないゲームの数学 的構造を調べる分野である。組合せゲーム理論においては、これまで主に 2 人ゲームに おいて研究されてきた。この論文では、多人数組合せゲーム理論について研究し、いく つかの結果を得ている。

第 1 章は導入である。NIM を例にゲームに関わる概念を説明し、Bouton による、正規 形および逆（misère）形における NIM の後手が必勝となる局面を特定する式を示して いる。その後に、本論文で導入する多人数での選好順序に基づくプレイの概念を直感的 に説明し、第 2 章以降の内容について概略を述べている。

第 2 章では、多人数組合せゲームに選好順序に基づくプレイの概念を導入し、Li に よる先行研究について説明している。多人数ゲームでは、自分に必勝戦略のないプレイ ヤーが、どのプレイヤーを勝者にするか選択できる場合があり、自分が勝者にならない 場合のプレイの目的が定まらないために、それぞれの局面に対する必勝戦略が定まらな くなる。ここでは、Krawec によるゲーム值の概念を修正して選好順序および選好順序に 基づくプレイの概念を導入し、選好順序に基づくプレイでは各局面の勝者が定まること を示している。また、特に重要な $\mathrm{m}$ 人ゲームの選好順序として、i $\mathrm{i}$ となる各非負整 数 i に対して i-misère プレイを定義している。その上で、Li のランクに基づく多人 数 NIM は 0-misère プレイと一致する概念であることを述べ、Li による、この場合の 必敗局面を特定する結果を紹介している。

第 3 章が本論文の中心である。

3.1 節では、本論文の主定理（定理 6) である、m 人 NIM をi-misère プレイとして 行う時に、与えられた局面が必敗局面かどうかを判定する式を与えている。それは、各 山の石の個数を 2 進表現したものに対し各桁ごとに $\mathrm{m}$ を法とした足し算をして得られ た值を、石の個数が 2 以上の山がある場合には 0 と、ない場合には i と比較するとい うものである。 $m=2$ の時、 $i$-misère プレイは、i=0では 2 人正規形、 $i=1$ では 2 人逆形ゲームにおける必勝戦略によるプレイと一致する。また、i = 0 の時は Li に よるランクに基づく $\mathrm{m}$ 人 NIM と一致する。定理 6 の判定式は、第 1 章、第 2 章で説 明した Bouton および Li によるこれらの場合の結果を全て特殊なケースとして包含す るものである。この定理の証明は 2 段階に分けて行われている。まず、定理 7 におい て、m 人不偏ゲームの i-misère プレイ一般について、必敗局面全体の集合を特徴付け る性質を示し、その証明を行っている。その後に、NIM の場合にその性質が山の石の個 数のどのような性質として表現できるかを考察して、定理 6 を導いている。

3.2 節では、NIM の石の取り方の規則を変更して得られるゲームである Moore のゲー 厶を多人数 i-misère プレイに拡張した場合の必敗局面を特定する式を、定理 7 を用い て求めている。Moore のゲームの多人数版については Li が研究を行なっていたが、そ れを、 $i=0$ の特殊な場合として包含する式を導き出している。

3.3 節では、i-misère プレイ以外の自然な対称性のある選好順序に基づくプレイであ る i-reverse プレイを考え、現在のプレイヤーが 2 番目に選好しているプレイヤーが 最終手番を打つ局面がもつ、ある性質を定理 11 において証明している。それは、 $\mathrm{n}$ 個 の山の中の、どんな $\mathrm{n}-1$ 個の山の石の個数が与えられても、それに対して、そのような 
局面となるような、残りの 1 つの山の石の個数が唯一に定まるという性質である。 第 4 章では、3 人プレイの NIM の場合に限定し、semi-normal と semi-reverse とい う対称性のない選好順序に基づくプレイを考え、そのもとで、それぞれの局面から始め た時に最後にプレイするプレイヤーを特定している。その值は、局面の情報を用いたき れいな式にはならず、また、選好順序がプレイヤーにより異なるため、どのプレイヤー からゲームを始めるかによって結果が異なる。定理 12 では、これらのことを慎重に調 べて、得られた結果を一覽表にしている。

第 5 章は結論で、本論文の結果を要約している。 


\section{（論文審査の結果の要旨）}

組合せゲーム理論は偶然性やプレイヤーに隠された情報の存在しないゲームの数学 的構造を調べる研究分野である。組合せゲーム理論においては、これまで主に、2人 ゲームの場合が研究されてきた。3 人以上のゲームでは、解析が複雑になるだけでは なく、通常の方法で遊べるゲームとして考えたのではゲームの必勝戦略が存在せず、 ゲームの設定から考える必要が生じてくる。本論文は、多人数不偏ゲームに選好順序 の概念を導入し、全てのプレイヤーの選好順序を共有知識としたプレイを考えて、そ のもとでのゲームの数学的構造について研究を行ったものである。

本論文の主定理は、m 人不偏ゲームにおいて、 $\mathrm{i} く \mathrm{~m}$ となる非負整数 $\mathrm{i}$ に対して i-misère という形の選好順序を考え、そのもとでプレイした時の必敗局面の集合を 特徵づける条件を与えたもの（定理 7)、そして、それを用いて、m 人 NIM（定理 6) および、m 人 Moore のゲーム(定理 10) という 2 つのゲームにおいて、各局面が i-misère プレイで必敗局面であるかどうかを判定する式を与えたものである。

多人数 i-misère プレイにおいては、各プレイヤーが自分を 0 番として、i 番目 の人を最終着手者とすることを目的としている。このことより、m が 2 の時には、0 -misère および 1-misère は、自分および相手が最終着手者となることを目的にし たゲームを意味しており、また、選好順序に基づくプレイは通常のプレイにおける必 勝戦略に従ったプレイと同じものとなる。よって、m が 2 の時の、 $i=0$ および、 $i=1$ の時の必勝局面は、正規形および逆形のゲームの必勝局面と一致する。Bouton による、2人 NIM の正規形と逆形の必勝局面を同定する結果は組合せゲーム理論の 原点となる重要なものであった。定理 6 は、この 2 つの結果を多人数 i-misère プ レイへ拡張したものとなっている。

2 人ゲームの場合、逆形のゲームは、正規形のゲームの勝ちと負けを反転させたも のである。それらを多人数 i-misère プレイに一般化して考えれば、iをパラメー ターとするゲーム族の異なる i の值の場合として考えられる。そして、その必敗局 面が i をパラメータとした式で判定できることは興味深い。また、2人不偏ゲーム の局面全体の集合は、必勝局面 (N-position と通常呼ばれている) と必敗局面(

P-position）に分けられたが、m 人不偏 i-misère プレイの場合には、局面全体は必 勝局面、必敗局面を含さ $\mathrm{m}$ 個の同值類に分類される。本論文では、その中で、必敗 局面のなす集合に対して、それを特定するきれいな特徵づけが与えられているが、必 勝局面には、必敗局面に1手で移動できる局面として以上の、より直接的な特徴づけ は容易ではないと思われる。2人不偏年一ムの場合には必勝局面は必敗局面の補集合 として必敗局面と同程度の複雑さの特徵づけが可能であった。それに対し、多人数不 偏 i-misère ゲームに一般化した時に、必敗局面のみにきれいな特徵づけが与えら れたことは、ゲーム局面のなす構造を考える上で興味深い。

多人数ゲームについては Li による先行研究があり、それは、本論文の 0-misère プレイによる $\mathrm{m}$ 人 NIM および $\mathrm{m}$ 人 Moore のゲームと一致した概念である。しか し、Li の結果は $i=0$ の場合だけを扱ったものである。また、この2つのゲームの 場合について判定式を直接求めたものであり、定理 7 のような、それらに共通した $\mathrm{m}$ 人不偏ゲームの局面集合のなす構造を明確にしたものではない。

本論文では、他の選好順序の場合についても解析を行い、i-reverse という選好順 序でプレイした時のある種の局面のなす性質について結果を得ている。2 正規形と逆形ゲームの必勝戦略によるプレイは、0-misère と 1-misère プレイと考 えられるし、また同時に、0-reverse と1-reverse プレイとも考えられる。つま 
り、i-misère と i-reverse は、2 人ゲームの正規形と逆形の多人数への異なる拡張 方法であり、それぞれの拡張が、2 人ゲームの性質の一部を引き継いでいるのは興味 深い。

さらに、本論文では、3 人プレイの場合に他の選好順序を考えて、そのもとで、そ れぞれの局面での必勝者を特定することも行っている。

このように、本論文で得られた結果は、斬新なアイデアに基づき多人数ゲームの新 しい構造を見つけたものであり、それは、2 人ゲームの自然な拡張となっている。本 論文の全ての議論は数学的に厳密であり、その面でも評価できる。

よって，本論文は博士（人間・環境学）の学位論文として価值あるものと認める。 また、平成 31 年 1 月 9 日、論文内容とそれに関連した事項について試問を行った 結果、合格と認めた。なお、本論文は、京都大学学位規程第 14 条第 2 項に該当す るものと判断し、公表に際しては、当該論文の全文に代えてその内容を要約したもの とすることを認める。 